\title{
TINJAUAN TERHADAP MEKANISME PENANGANAN PERKARA PERSAINGAN USAHA TIDAK SEHAT
}

\author{
Oleh : Nina Herlina, S.H., M.H. ${ }^{*}$
}

\begin{abstract}
The mechanism of handling unhealthy competition cases is carried out by the Commission as regulated in Article 38 through Article 46 of Law Number 5 Year 1999 concerning Prohibition of Monopolistic Practices and Unfair Competition. If the Business Competition Supervisory Commission (KPPU) finds evidence of violation of Law Number 5 of 1999 by business actors, KPPU may impose administrative sanctions on the business actor, in addition to regulating administrative sanctions in Law Number 5 Year 1999 as well regulates the sanctions for violations of this law which may be subject to criminal penalties, namely in the form of principal and additional criminal sanctions. The principal penalty is in the form of a fine, while for additional criminal sanction by referring to Article 10 of the Criminal Code.
\end{abstract}

Keywords: Handling, Unfair competition

\section{Abstrak}

Mekanisme penanganan perkara persaingan tidak sehat dilaksanakan oleh Komisi sebagaimana diatur dalam Pasal 38 sampai dengan Pasal 46 UndangUndang Nomor 5 Tahun 1999 tentang Larangan Praktek Monopoli dan Persaingan Tidak Sehat. Apabila Komisi Pengawasan Persaingan Usaha (KPPU) menemukan adanya bukti telah terjadinya pelanggaran terhadap Undang-Undang Nomor 5 Tahun 1999 oleh pelaku usaha maka KPPU dapat memberikan sanksi administrative terhadap pelaku usaha tersebut, selain mengatur tentang sanksi administrative dalam Undang-Undang Nomor 5 Tahun 1999 juga mengatur tentang sanksi pelanggaran terhadap undang-undang ini yang dapat dikenakan ancaman pidana, yaitu berupa pidana pokok dan pidana tambahan. Pidana pokok itu berupa pidana denda sedangkan untuk pidana tambahan dengan menunjuk pada pasal $10 \mathrm{Kitab}$ Undang-Undang Hukum Pidana.

Kata Kunci : Penanganan, Persaingan Tidak Sehat

\section{Pendahuluan}

Kondisi persaingan dalam dunia usaha merupakan bentuk karakteristik utama dari sistem ekonomi pasar yang memang lebih banyak memberikan keuntungan kepada para pelaku usaha dibandingkan dengan kondisi antipersaingan yang menghendaki adanya pemusatan kekuatan ekonomi dan menghambat pelaku usaha pesaingnya untuk masuk ke dalam pasar.

\footnotetext{
*) Dosen Tetap Fakultas Hukum Universitas Galuh
} 
Lahirnya Undang-Undang Nomor 5 Tahun 1999 tentang Larangan Praktek Monopoli dan Persaiangan Tidak Sehat merupakan perangkat hukum untuk menunjang sistem ekonomi pasar yang saat ini berlaku di Indonesia. Undangundang ini juga mengatur tentang larangan monopoli. Monopoli sebenarnya tidak dilarang selama posisi pasar yang bersifat monopolistis itu diperoleh dan dipertahankan melalui kemampuan, prediksi, atau kejelian bisnis yang tinggi. Seperti misalnya suatu perusahaan yang mampu melakukan inovasi sehingga terhadap penemuan tersebut dan perusahaan yang demikian mempunyai posisi dominan pada produk tersebut.

Menurut ketentuan Pasal 2 Undang-Undang Nomor 5 Tahun 1999 tentang Larangan Praktek Monopoli dan Persaingan Usaha Tidak Sehat, tujuan dari pembentukan Undang-Undang tentang Larangan Praktek Monopoli dan Persaingan Usaha Tidak Sehat adalah menjaga kepentingan umum dan meningkatkanefisiensi ekonomi nasional sebagai salah satu upaya untuk menigkatkan kesejahteraan rakyat. (Munir Fuady, 2002 : 234).

Berdasarkan ketentuan dalam Undang-Undang Nomor 5 Tahun 1999, melarang adanya perjanjian dan perbuatan yang bersifat anti persaingan serta adanya penyalahgunaan posisi yang dominan dari pelaku usaha. Perjanjian yang dilarang oleh undang-undang ini adalah oligopoly, penetapan harga, pembagian wilayah, pemboikotan, kartelisasi, trust, integrasi vertical, perjanjian tertutup dan lain sebagainya. Sedangkan untuk kegiatan yang dilarang seperti monopoli, monopsoni, penguasaan pasar, dan persekongkolan. Untuk posisi dominan mengatur mengenai posisi dominan yang dilarang, jabatan rangkap, pemilikan saham, merger, akuisisi dan konsolidasi, disamping melarang perjanjian dan perbuatan yang bersifat anti persainagan. Selain itu Undang-Undang Nomor 5 Tahun 1999 mengatur tentang penegakan hukum dan tata cara penanganan perkara dan sanksinya. Permasalahan yang seringkali terjadi adanya persaingan usaha tidak sehat antara para pelaku usaha dan antara para pelaku usaha harus mengetahui tentang penanganan permasalahan tersebut. Untuk itu yang menjadi kajian dalam permasalahan ini adalah bagaimakah mekanisme dan penanganan perkara persaingan tidak sehat berdasarkan Undang-Undang Nomor 5 Tahun 1999 tentang Larangan Praktek Monopoli dan Persaiangan Tidak Sehat.

Penelitian ini bertujuan untuk mengetahui bagaimana mekanisme dan penanganan perkara persaingan usaha tidak sehat berdasarkan Undang-Undang 
Nomor 5 Tahun 1999 tentang Larangan Praktek Monopoli dan Persaingan Tidak Sehat.

Adapun kegunaanya secara teoritis dapat memberikan manfaat bagi perkembangan ilmu pengetahuan khususnya Hukum Persaingan dan bidang lainnya seperti Hukum Perlindungan Konsumen.

Metode penelitian yang digunakan yaitu yuridis normative dan komparatif yaitu yang menitikberatkan pada penelitian kepustakaan(data sekunder). Adapun caranya yaitu menelaah dan menganalisis berbagai peraturan perundangundangan setelah terlebih dahulu menginventariasasi dan menemukan asas-asas hukum serta menemukan hukum (inconcreto) yang berkaitan dengan permasalahan dan hasilnya dipaparkan secara deskriptif analisis.

\section{Tinjauan Pustaka}

\section{A. Persaingan Usaha}

Menurut Thomas J. Anderson menyatakan bahwa persaingan dapat terjadi dalam berbagai bidang. Persaingan dalam bidang ekonomi merupakan salah satu bentuk persaingan yang paling utama di antara sekian banyak persaingan antar manusia, kelompok masyarakat, atau bahkan bangsa. Salah satu bentuk persaingan dalam di bidang ekonomi adalah persaingan usaha (business competition) yang secara sederhana bisa didefinisikan sebagai persaingan antara para penjual dalam "merebut" pembeli dan pangsa pasar (Arie Siswanto, 2004 : 13-14). Kondisi persaingan dalam dunia usaha merupakan bentuk karakteristik utama dari sistem ekonomi pasar yang memang lebih banyak memberikan keuntungan kepada para pelaku usaha dibandingkan dengan kondisi anti-persaingan yang menghendaki adanya pemusatan kekuatan ekonomi dan menghambat pelaku usaha pesaingnya untuk masuk ke dalam pasar.

Berdasarkan pendapat di atas, maka secara umum dapat dikatakan bahwa kondisi anti-persaingan, cenderung akan berdampak buruk di pasar. Untuk itu, diperlukan suatu regulasi dari pemerintah dalam kerangka hukum persaingan usaha yang dijadikan sebagai landasan hukum untuk dapat mencegah atau menindak pelaku usaha yang menciptakan kondisi antipersaingan tersebut. 
Hukum persaingan usaha adalah seperangkat aturan hukum yang mengatur mengenai segala aspek yang berkaitan dengan persaingan usaha, yang mencakup hal-hal yang boleh dilakukan dan hal-hal yang dilarang dilakukan oleh pelaku usaha (Hermansyah, 2008 : 2). Hukum persaingan (Competition Law) merupakan instrumen hukum yang menentukan tentang bagaimana persaingan itu harus dilakukan (Arie Siswanto, $2004: 25$ ).

Berdasarkan pendapat tersebut dapat diketahui secara umum bahwa yang dimaksud dengan hukum persaingan usaha adalah seperangkat aturan hukum yang mengatur perilaku pelaku usaha dalam menjalankan usahanya dengan tujuan menciptakan kesempatan berusaha yang sama dan menghindari adanya pemusatan kekuatan ekonomi.

Keberadaan hukum persaingan usaha adalah untuk mengupayakan secara optimal terciptanya persaingan usaha yang sehat (fair competition) dan efektif pada suatu pasar tertentu, dengan tujuan mendorong agar pelaku usaha melakukan efisiensi sehingga mampu bersaing dengan para pesaingnnya (Hermansyah, 2008 : 13). Saat ini Indonesia telah memiliki pengaturan tentang persaingan usaha sebagai suatu sistem dalam tata urutan peraturan perundang-undangan yang digunakan untuk menata terselenggaranya proses dan kegiatan persaingan usaha di Indonesia yaitu Undang-Undang Nomor 5 Tahun 1999 tentang Larangan Praktek Monopoli dan Persaiangan Tidak Sehat.

B. Tugas dan Wewenang Komisi Pengawas Persaingan Usaha (KPPU)

Komisi Pengawas Persaingan Usaha (KPPU) merupakan suatu lembaga independen yang terlepas dari pengaruh kekuasaan pemerintah serta pihak lain dan bertanggung jawab kepada Presiden.

Berdasarkan Pasal 35 Undang-Undang Nomor 5 Tahun 1999, Tugas Komisi Pengawas Persaingan Usaha (KPPU), adalah sebagai berikut :

a. melakukan penilaian terhadap perjanjian dan kegiatan usaha/tindakan pelaku usaha yang dilarang oleh undang-undang ini serta penilaian terhadap ada atau tidaknya penyalahgunaan posisi dominan;

b. mengambil tindakan sesuaia dengan wewenang yang diberikan;

c. member saran dan pertimbangan terhadap kebijakan pemerintah yang berkaitan dengan praktek monopoli dan persaingan usaha tidak sehat;

d. menyusun pedoman dan atau publikasi yang berkaitan dengan undangundang ini; 
e. memberikan laporan secara berkala atas hasil kerja kepada Presiden dan Dewan Perwakilan Rakyat.

Adapun wewenang KPPU sebagaimana diatur dalam Pasal 36 UndangUndang Nomor 5 Tahun 1999, adalah sebagai berikut :

1. Menerima laporan dari dan atau dari pelaku usaha tentang dengan terjadinya praktek monopoli dan atau persaingan usaha tidak sehat.

2. Melakukan penelitian tentang dugaan adanya kegiatan usaha dan atau tindakan pelaku usaha yang dapat mengakibatkan praktek monopoli dan atau persaingan usaha tidak sehat.

3. Melakukan penyelidikan dan atau pemeriksaan terhadap kasus dugaan praktek monopoli dan atau persaingan usaha tidak sehat yang dilaporkan oleh masyarakat atau oleh pelaku usaha atau yang ditemukan oleh komisi sebagai hasil dari penelitiannya;

4. Menimpilkan hasil penyelidikan dan atau pemeriksaan tentang ada atau tidak adanya praktek monopoli dan atau persaingan usaha tidak sehat.

5. Memanggil pelaku usaha yang diduga telah melakukan penyelewengan terhadap ketentuan undang-undang ini.

6. Memanggil dan menghadirkan saksi, saksi ahli, dan setiap orang yang dianggap mengetahui pelenggaran terhadap ketentuan undang-undang ini;

7. Meminta bantuan penyidik untuk menghadirkan para pelaku usaha, saksi-saksi ahli, atau setiap orang bagaimana dimaksud huruf $c$ dan $f$ yang tidakn bersedia memenuhi panggilan komisi.

8. Meminta keterangan dari instansi pemerintah dalam kaitannya dengan penyelidikan dan atau penulisan terhadap pelaku usaha yang melanggar ketentuan undang-undang ini.

9. Mendapatkan, meneliti dan atau menilai surat, dokumen, atau alat bukti lain guna penyelidikan dan atau pemeriksaan.

10. Memutuskan dan menetapkan ada atau tidak adanya kerugian pihak pelaku usaha lain atau masyarakat.

11. Memberitahukan putusan komisi kepada pelaku usaha yang diduga melakukan praktek monopoli dan atau persaingan usaha tidak sehat.

12. Menjatuhkan sanksi berupa tindakan administratif kepada pelaku usaha yang melanggar ketentuan undang-undang ini.

Komisi ini merupakan badan yang mempunyai kewenangan yang sangat

luas dalam menangani perkara persaingan tidak sehat sebagaimana diamanatkan dalam Undang-Undang Nomor 5 Tahun 1999 tentang Larangan

Praktek Monopoli dan Persaingan Tidak Sehat.

\section{Pembahasan}

Beberapa Pasal yang mengatur mengenai mekanisme penanganan perkara persaingan usaha tidak sehat yaitu dalam Pasal 38 sampai dengan Pasal 46 Undang-Undang Nomor 5 Tahun 1999 tentang Larangan Praktek Monopoli dan Persaiangan Tidak Sehat. Perkara yang timbul karena pelanggaran undang- 
undang ini dapat diajukan karena adanya pengaduan dan dapat juga tanpa adanya pengaduan.

Adapun prosedur penanganan perkara persaingan tidak sehat yaitu pihakpihak yang dapat mengajukan perkara atas dugaan telah terjadi praktek persaingan usaha tidak sehat kepada komisi pengawasan persaingan usaha. Adapun pihak yang dapat mengajukannya, yaitu anggota masyarakat luas, pihak yang dirugikan atau praktek bisnis yang bersangkutan, misalnya pelaku usaha pesaing dan KPPU sendiri.

Pemeriksaan pendahuluan atas pengaduan atau gugatan yang ditunjukan kepada KPPU dilakukan selambat-lambatnya 30 (tiga puluh) hari setelah pengaduan tersebut diterima dan harus diputuskan apakah proses pemeriksaan tersebut layak diteruskan atau tidak. Pelaku usaha yang diadakan karena dicurigai telah melakukan praktek monopoli dan atau persaingan usaha tidak sehat wajib bekerja sama atau beritikad baik untuk meluncurkan proses pemeriksaan dengan misalnya menyerahkan alat bukti yang diperlukan dan memberikan keterangan serta bersedia diperiksa oleh KPPU.

Apabila KPPU memutuskan perlunya pemeriksaan lanjutan maka proses pemeriksaan lanjutan tersebut paling lama 60 (enam puluh) hari. KPPU wajib membacakan putusannya secara terbuka selambat-lambatnya 30 (tiga puluh) hari sejak 8 Undang-undang Nomor 5 Tahun 1999 Pasal 30 diterimanya pemberitahuan tersebut, pelaku usaha itu wajib melaksanakan isi putusan KPPU tersebut. Apabila bersangkutan keberatan terhadap isi putusan KPPU tersebut. Apabila yang bersangkutan keberatan terhadap isi putusan KPPU, maka dia dapat mengajukan keberatan/banding ke Pengadilan Negeri.

Pengadilan Negeri ini kemudian harus mulai memeriksa permohonan banding tersebut dalam waktu 14 (empat belas) hari sejak diterimanya permohonan banding, dan jangka waktu pemeriksaan itu adalah 30 (tiga puluh) hari. Terhadap Putusan Pengadilan Negeri dapat pula dimintakan kasasi langsung ke Mahkamah Agung yang kemudian Mahkamah Agung harus menjatuhkan putusannya dalam waktu 30 (tiga puluh) hari sejak tanggal diterimanya permohonan kasasi tersebut.

Apabila pelaku usaha terbukti bersalah tidak juga melaksanakan isi petugas KPPU dan tidak pula banding ke Pengadilan Negeri, maka KPPU dapat menyerahkan suratnya itu ke penyidik untuk dilakukan penyidikan sesuai dengan 
hukum acara pidana yang berlaku. Petugas KPPU tersebut dianggap merupakan bukti permulaan yang cukup bagi penyidik untuk melakukan penyidikan.

Komisi diberi kewenangan untuk menjatuhkan sanksi berupa tindakan administrative terhadap pelaku usaha yang melanggar Undang-Undang Nomor 5 Tahun 1999, berupa :

a. penetapan pembatalan perjanjian yang dilarang oleh Undang-Undang Nomor 5 Tahun 1999 tentang Larangan Praktek Monopoli dan Persaiangan Tidak Sehat;

b. perintah kepada pelaku usaha untuk menghentikan integrasi vertical;

c. perintah kepada pelaku usaha untuk menghentikan kegiatan yang terbukti menimbulkan praktek monopoli dan atau menyebabkan persiangan usaha tidak sehat dan merugikan masyarakat;

d. perintah kepada pelaku usaha untuk menghentikan penyalahgunaan posisi dominan;

e. penetapan pembatalan atas merger atau akuisisiatau konsilidasi badan yang dilarang oleh undang-undang;

f. penetapan pembayaran ganti rugi;

g. pengenaan denda sebagaimana diatur dalam pasal 47 Undang-Undang Nomor 5 Tahun 1999.

Selain mengatur tentang sanksi administrative dalam Undang-Undang Nomor 5 Tahun 1999 juga mengatur tentang sanksi pelanggaran terhadap undang-undang ini yang dapat dikenakan ancaman pidana, yaitu berupa pidana pokok dan pidana tambahan. Pidana pokok itu berupa pidana denda sedangkan untuk pidana tambahan dengan menunjuk pada pasal 10 Kitab Undang-Undang Hukum Pidana, berupa :

a. pencabutan ijin usaha;

b. larangan kepada pelaku usaha yang telah terbukti melakukan pelanggran terhadap Undang-Undang Nomor 5 Tahun 1999 untuk menduduki jabatan direksi atau komisaris sekurang-kurangnya 2 tahun dan selama-lamanya 5 tahun;

c. penghentian kegiatan atau tindakan tertentu yang menyebabkan timbulnya kerugian kepada pihak lain.

Setelah adanya pemberitahuan putusan, maka akan diikuti dengan pelaksanaan putusan dan menyampaikan laporan pelaksanaan putusan kepada Komisi. Pelaku usaha yang keberatan atas putusan Komisi diberikan kesempatan untuk mengajukan keberatannya kepada Pengadilan Negeri, dan apabila tidak terdapat keberatan, maka putusan Komisi dinyatakan telah mempunyai kekuatan hukum yang tetap dan dapat dimintakan penetapan eksekusi kepada Pengadilan Negeri. Sedangkan apabila pelaku usaha tidak melaksanakan putusan Komisi, 
maka Komisi akan menyerahkan putusan tersebut kepada penyidik untuk dilakukan penyidikan. Putusan Komisi yang tidak dilaksanakan itu dianggap sebagai bukti permulaan bagi penyidik untuk digunakan dalam melakukan penyidikan lebih lanjut.

Setelah Pengadilan Negeri melakukan pemeriksaaan terhadap pelaku usaha, maka Pengadilan Negeri menjatuhkan putusannya. Upaya hukum selanjutnya apabila pelaku usaha keberatan terhadap putusan yang telah dijatuhkan dapat mengajukan kasasi kepada mahkamah Agung. Putusan Komisi yang diajukan tersebut, dalam pemeriksaan di Pengadilan Negeri dianggap penyidik sebagai bukti permulaan yang cukup untuk digunakan penyidikan sesuai dengan ketntuan yang berlaku.

Dalam perkara persaingan usaha tidak sehat yang menimbulkan kerugian terhadap Negara dapat dikatagorikan sebagai perbuatan pidana artinya perbuatan yang diancam dengan suatu pidana terhadap pelakunya. Disamping itu kerugian bisa terjadi terhadap kepentingan pelaku usaha pesaingnya, maka dapat diajukan dengan suatu gugatan kepada pelakunya.

Berdasarkan Kitab Undang-undang Hukum Perdata, terdapat 2 dasar hukum untuk melakukan tuntutan hak (gugatan) yang berupa tuntutan ganti rugi yaitu berdasarkan wanprestasi (pasal 1243 KUHPerdata) dan berdasarkan perbuatan melanggar hukum (pasal 1365 KUHPerdata). Akan tetapi nampaknya dalam perkara persaingan usaha lebih tepat menggunakan dasar perbuatan melawan hukum untuk meminta ganti rugi. Dalam perkara persaingan usaha ini unsur melanggar hukum lebih menekankan pada bertentangan dengan kewajiban hukum dari pelaku. Maksud dari kewajiban hukum adalah kewajiban menurut undang-undang. (R. Setiawan, 1987 : 83) Kewajiban hukum di sini berupa larangan adanya perjanjian dan perbuatan yang bersifat anti persaingan sebagaimana diatur dalam Undang-Undang Nomor 5 Tahun 1999 tentang Larangan Praktek Monopoli dan Persaiangan Tidak Sehat.

Mengenai perkara perdata adalah berkaitan dengan penetapan ganti rugi untuk pelaku usaha pesaingnya yang dirugikan. Apabila ini berkaitan dengan perkara perdata, maka proses pembuktiannya tentu berpedoman pada ketentuan Hukum Acara Perdata yang berlaku karena undang-undang ini sama sekali tidak mengaturnya. Kewenangan Komisi sebagai lembaga kuasi-judisial dianggap terlalu luas karena sesuai dengan Pasal 47 huruf $f$ dan g Undang-Undang Nomor 
5 Tahun 1999 tentang Larangan Praktek Monopoli dan Persaiangan Tidak Sehat diberi kewenangan untuk menjatuhkan putusan penetapan pembayaran ganti rugi dan pengenaan denda padahal kewenangan itu berada di tangan lembaga judisial yaitu Pengadilan Negeri (Normin S. Pakpahan, 1994 : 16)

Di dalam Undang-Undang Nomor 5 Tahun 1999 tentang Larangan Praktek Monopoli dan Persaiangan Tidak Sehat, tidak dibedakan sama sekali apakah perkara persaingan usaha itu merupakan perkara pidana dan perkara perdata. Sementara itu ketentuan yang ada lebih menitikberatkan pada aspek perkara pidana, tetapi ada juga ketentuan mengenai pembayaran ganti kerugian. Oleh karena itu, persoalan gugatan ganti rugi bisa dilakukan langsung kepada Pengadilan Negeri, setelah Komisi telah memutuskan adanya suatu pelanggaran terhadap Undang-Undang Nomor 5 Tahun 1999.

\section{Kesimpulan}

Untuk mengupayakan secara optimal terciptanya persaingan usaha yang sehat (fair competition) dan efektif pada suatu pasar tertentu, dengan tujuan mendorong agar pelaku usaha melakukan efisiensi sehingga mampu bersaing dengan para pesaingnnya, akan tetapi dalam dunia usaha seringkali terjadinya persaingan usaha tidak sehat sehingga menimbulkan kerugian bagi pesainnya. untuk mendapatkan tuntutan hak pesaing, maka terdapat mekanisme penanganan perkara persaingan tidak sehat dengan melakukan laporan kepada KPPU sebagaimana diatur dalam Pasal 38 sampai dengan Pasal 46 UndangUndang Nomor 5 Tahun 1999 tentang Larangan Praktek Monopoli dan Persaingan Tidak Sehat.

Komisi Pengawasan Persaingan Usaha selain mengatur tentang sanksi administrative dalam Undang-Undang Nomor 5 Tahun 1999 juga mengatur tentang sanksi pelanggaran terhadap undang-undang ini yang dapat dikenakan ancaman pidana, yaitu berupa pidana pokok dan pidana tambahan. Pidana pokok itu berupa pidana denda sedangkan untuk pidana tambahan dengan menunjuk pada pasal 10 Kitab Undang-Undang Hukum Pidana.

\section{Daftar Pustaka}

Fuady, Munir, 1999, Hukum Anti Monopoli (Menyongsong Era Persaingan Usaha Sehat), Bandung, PT Citra Aditya Bakti. 
Hermansyah, 2008, Pokok-Pokok Hukum Persaingan Usaha di Indonesia, Jakarta, Kencana Prenada Media.

Maulana, Insan Budi, 2000, Catatan Singkat Undang-Undang Nomor 5 Tahun 1999, Bandung, Citra Aditya Bakti.

Pakpahan, Normin S., 1994, Pokok-Pokok Pikiran Tentang Hukum Persaingan Usaha, Jakarta, ELIPS.

Setiawan, R., 1987, Pokok-Pokok Hukum Perikatan, Bandung, Binacipta.

Subekti, R. dan R. Tjitrosudibio, 2009, Kitab Undang-Undang Hukum Perdata, Jakarta, Balai Pustaka.

\section{Perundang-undangan}

Undang-Undang Republik Indonesia Nomor 5 Tahun 1999 tentang Larangan Praktek Monopoli dan Persaingan Usaha Tidak Sehat 